Majalah Biomorfologi

Volume 30 Number 2, July 2020

p.ISSN:0215-8833, e.ISSN: 2716-0920, DOI:10.20473/mbiom.v30i2.2020.59-66

\title{
Factors related to the incidence of HIV/AIDS among shemale in Surabaya, Indonesia
}

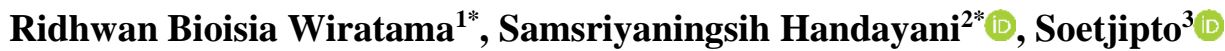 \\ ${ }^{1}$ Medical Program, Faculty of Medicine, Universitas Airlangga, Surabaya, Indonesia, \\ ${ }^{2}$ Department of Public Health and Preventive Medicine, Faculty of Medicine, Universitas Airlangga, \\ Surabaya, Indonesia, ${ }^{3}$ Department of Psychiatry, Faculty of Medicine, Universitas Airlangga, \\ Dr. Soetomo General Academic Hospital, Surabaya, Indonesia
}

\begin{tabular}{l}
\hline Article Info \\
\hline Article history: \\
Received Sep 3, 2019 \\
Revised May 20, 2020 \\
Accepted May 30, 2020 \\
Published Jul 1, 2020 \\
\hline
\end{tabular}

Keywords:

HIV

AIDS

Shemale

Condom

Family support

\begin{abstract}
Background: Acquired Immunodeficiency Syndrome (AIDS) is one of the diseases that cause death in the world caused by the Human Immunodeficiency Virus (HIV). Since it was first discovered in 1987 until December 2017, the number of person with AIDS was 102,667, and the number of person with HIV infections was 280,623. HIV/AIDS cases in East Java occupy the second highest position in Indonesia. Surabaya is the first city in East Java with 934 HIV cases in 2017. Shemale is one of the groups at risk of getting HIV/AIDS with prevalence was $24.82 \%$. Objective: The purpose of this study was to analyze the factors that influence shemale related to the incidence of HIV/AIDS in Surabaya. Materials and Methods: This study was an analytic research using a cross sectional approach. The subject was 80 shemale respondents. Data were collected using questionnaires then analyzed using Chisquare test, with $\alpha=0.05$. Results: The highest age group was 42-46 years $(22.5 \%)$, the last level of education was dominated by high school (41.3\%), and the most types of work were private employees $(47.4 \%)$. There was no correlation between predisposing factors in the form of knowledge about HIV/AIDS and respondent's HIV status $(p=0.729)$, there was no correlation between enabling factors in the form of condoms and respondent's HIV status ( $p=0.624)$, there was no correlation between the reinforcing factor in the form of family support with the HIV status of the respondent $(\mathrm{p}=0.674)$ and there was no correlation between preventive behavior and the HIV status of the respondent $(p=0.540)$. Conclusion: The need for support between shemales for the dangers of HIV/AIDS and shemale should be more aware of their own health and environment with their social patterns.
\end{abstract}

(c) (i)

\section{Corresponding Author:}

Ridhwan Biosia Wiratama

Jalan P. Trunojoyo VII No. 41C, Pamekasan, Indonesia

Ridhwan.biosia@gmail.com

Samsriyaningsih Handayani

Department of Public Health and Preventive Medicine, Faculty of Medicine, Universitas Airlangga Jl. Mayjen. Prof. Moestopo no. 47, Surabaya 60131, East Java, Indonesia samsriyaningsih-h@fk.unair.ac.id 


\section{BACKGROUND}

Human Immunodeficiency Virus (HIV) is a virus that causes Acquired Immunodeficiency Syndrome (AIDS), which can damage the human immune system and result in decreased immunity so that it is easy to catch infectious diseases by attacking white blood cells (lymphocytes) in the body (Marubenny, et al., 2013). HIV is found in body fluids, especially in blood, sperm, vaginal fluids, and breast milk (Ministry of Health, Republic of Indonesia, 2007). According to data from the United Nations Program on HIV/AIDS (UNAIDS) - the WHO (World Health Organization) that deals with AIDS, HIV cases in the world in 2015 reached 2.1 million cases, of which 1.1 million people died of AIDS and as many as 150,000 (down from 290,000 in 2010) patients under 15 years of age (WHO, 2015). Until now, HIV/AIDS has spread in 386 districts/cities throughout Indonesia. In 2015, 30,935 new HIV positive cases were recorded, while new AIDS cases were 6,081 cases (Ministry of Health, Republic of Indonesia, 2016). The proportion of risk factors for people with HIV/AIDS through heterosexual relationships is the mode of transmission with the highest percentage at $82.8 \%$, followed by homosexuals at 7.4\% and perinatal at 4.0\% (Ministry of Health, Republic of Indonesia, 2016).

HIV prevalence based on population at risk, shemale in Indonesia occupy the second highest position after IDU (injecting drug users), which reached $24.33 \%$ in 2007, then fell to $21.85 \%$ in 2011 and experienced an increase back to $24.8 \%$ in 2015 (Ministry of Health, Republic of Indonesia, 2016). The number of shemale in Indonesia in 2010 was around 31,179, with the highest distribution in East Java, namely 4,170 shemale (Social Welfare Data and Information Center, Republic of Indonesia, 2012). Although the number of shemale in Indonesia is not large, the main target tends to be young men who may be a potential "bridge" to the general population, so that the shemale has the potential to have a major impact on the HIV/AIDS epidemic in Indonesia. If there is no significant increase in prevention efforts, the HIV/AIDS epidemic will increase from year to year, resulting in increased morbidity and mortality.

According to Prabawanti et al. (2011), shemale are biologically male who dress appropriately as women, adopt women's social roles and behavior, identify themselves as shemale, and socialize regularly with fellow shemale community (Prabawanti et al., 2011). The prevalence of HIV among shemale in three major cities, namely, Jakarta (34.0\%), Surabaya (25.2\%), and Bandung (14.0\%), shows a widespread HIV epidemic among shemale. The relatively high prevalence of HIV among shemale is in line with the poor distribution of condoms and lubricants, poor understanding of the benefits of clinical services, and low support for HIV-positive shemale. This prevalence makes tackling HIV transmission to shemale quite difficult. The risky sexual behavior of shemale puts them, their clients, and their sex partners at high risk of contracting HIV (Ministry of Health, Republic of Indonesia, 2007).

\section{OBJECTIVE}

This study aimed to analyze the factors that influence HIV/AIDS incidence among shemale in Surabaya.

\section{MATERIALS AND METHODS}

This research was an analytical study with a study approach of cross-sectional, or where data collection is carried out once simultaneously. The research sample was taken by snowball sampling, where the data sources ranged from a small amount to a large number. The number of samples used in this study was 80 shemale respondents. Data were collected using a questionnaire and then analyzed in the Statistical Package for the Social Sciences (SPSS) application using the test Chi-square, with $\alpha=0.05$. The time of data collection for this research is June 2018 to May 2019. Data obtained were primary data, namely the results of filling out the questionnaire by 80 shemale in Surabaya. The variables studied were a profile of sociodemography and a description of risk factors against the incidence of HIV/AIDS.

\section{RESULTS}

Distribution of respondents based on sociodemographics 
The respondents' distribution based on a sociodemographic description can be distinguished according to age, last education, and occupation of the respondents. Table 1 shows that the respondents' average age is 39.4 years, with most respondents aged 30 years and 35 years. The age interval of the respondents was between 22 years and 59 years. Table 2 shows the frequency distribution of respondents based on their latest education.

Table 1. Frequency distribution of respondents by age group

\begin{tabular}{ccl}
\hline $\begin{array}{l}\text { Age group } \\
\text { (years) }\end{array}$ & $\begin{array}{l}\text { Frequency } \\
\text { (people) }\end{array}$ & $\begin{array}{l}\text { Percentage } \\
(\%)\end{array}$ \\
\hline $22-26$ & 6 & 7,5 \\
$27-31$ & 14 & 17,5 \\
$32-36$ & 12 & 15,0 \\
$37-41$ & 12 & 15,0 \\
$42-46$ & 18 & 22,5 \\
$47-51$ & 12 & 15,0 \\
$52-56$ & 5 & 6,3 \\
$57-61$ & 1 & 1,3 \\
\hline Total & 80 & 100 \\
\hline
\end{tabular}

Table 2. Frequency distribution of respondents by the latest education

\begin{tabular}{lcc}
\hline Latest Education & $\begin{array}{l}\text { Frequency } \\
\text { (people) }\end{array}$ & $\begin{array}{l}\text { Percentage } \\
(\%)\end{array}$ \\
\hline Elementary school & 16 & 20,0 \\
Junior high school & 21 & 26,3 \\
Senior high school & 33 & 41,3 \\
Vocational high & & \\
school & 9 & 11,3 \\
Bachelor degree & 1 & 1,3 \\
\hline Total & 80 & 100 \\
\hline
\end{tabular}

Based on Table 2, on average, respondents have met the minimum criteria for the 12-year compulsory education of the Ministry of Education and Culture. The results showed that the highest percentage of education was Senior high school, $41.3 \%$ with 33 respondents. Table 3 shows the frequency distribution of respondents by type of work.

Table 3. Frequency distribution of respondents by type of work

\begin{tabular}{llc}
\hline Type of work & Frequency & $\begin{array}{l}\text { Percentage } \\
(\%)\end{array}$ \\
\hline Civil servants & 1 & 1,3 \\
Private & 38 & 47,5 \\
Self-employed & 11 & 13,8 \\
Prostitute & 8 & 10,0 \\
Salon employees & 22 & 27,5 \\
\hline Total & 80 & 100 \\
\hline
\end{tabular}

Based on Table 3, it is found that most respondents type of work is private, $47.5 \%$ with a total of 38 respondents, and it is shown that all respondents have an income each month.

\section{Distribution of respondents based on risk factors}

The risk factors for HIV/AIDS incidence among shemale in Surabaya can be divided into predisposing factors, enabling factors, and reinforcing factors. Predisposing factors include knowledge of HIV/AIDS, enabling factors including the availability of condoms, reinforcing factors including 
family support, and HIV/AIDS prevention behavior. The distribution of respondents based on risk factors is shown in Table 4.

Table 4. Frequency distribution of respondents by risk factors

\begin{tabular}{cll}
\hline Risk factors & $\begin{array}{c}\text { Frequency } \\
\text { (people) }\end{array}$ & $\begin{array}{l}\text { Percentage } \\
(\%)\end{array}$ \\
\hline Knowledge of HIV/AIDS & Good: 37 & 46,3 \\
& Poor: 43 & 53,8 \\
Availability of condoms & Good: 56 & 70,0 \\
& Poor: 24 & 30,0 \\
Family support & Good: 5 & 6,3 \\
& Poor: 75 & 93,8 \\
HIV/AIDS prevention & Good: 60 & 75,0 \\
behavior & Poor: 20 & 25,0 \\
\hline Total & 80 & 100 \\
\hline
\end{tabular}

Based on Table 4, it is shown that out of 80 respondents, $46.3 \%$ of respondents could answer all UNAIDS questions correctly; as much as $70 \%$ of respondents stated that there were condoms to be used for sexual intercourse; $6.3 \%$ of respondents indicated that they received assistance from parents and relatives in the form of information about HIV, the importance of using condoms, the dangers of HIV and discussions about work; and as many as $75 \%$ of respondents used condoms and lubricants during sexual intercourse and also took other precautions aimed at preventing HIV infection.

\section{Relationship between predisposing factors and HIV status}

Relationship between predisposing factors for HIV status and the number of respondents who stated HIV status as many as 36 respondents are shown in Table 5.

Table 5. Relationship between knowledge about HIV/AIDS and HIV status

\begin{tabular}{lllc}
\hline Predisposing & \multicolumn{2}{c}{ HIV Status } & \\
factors & Positive & Negative & Total \\
\hline Poor knowledge & 6 & 12 & 18 \\
Good knowledge & 7 & 11 & 18 \\
\hline Total & 13 & 23 & 36 \\
\hline
\end{tabular}

Based on the Chi-square test result, the value of $p=0.5$ was obtained, which means that there was no difference between respondents with bad or good knowledge of HIV/AIDS on HIV status. Based on the result of the count test contingency coefficient, the value of $p=0.729$, which means that there is no relationship between knowledge about HIV and HIV status.

\section{Relationship between enabling factors and HIV status}

Relationship between enabling factors in the form of condom availability and HIV status and the number of respondents who stated their HIV status was shown in Table 6.

Table 6. Relationship between condom availability and HIV status

\begin{tabular}{cllc}
\hline \multirow{2}{*}{ Enabling Factors } & \multicolumn{2}{c}{ HIV Status } & \multirow{2}{*}{ Positive } \\
& 5 & 7 & Negative \\
\hline Poor availability of condoms & 8 & 16 & 18 \\
Good availability of condoms & 13 & 23 & 18 \\
\hline Total & & & 36 \\
\hline
\end{tabular}

Based on the chi-square test results, the $\mathrm{p}$ value was 0.447 , which means that there is no difference between respondents with the availability of bad or good condoms on HIV status. Based on the results of the count test contingency coefficient, the value of $\mathrm{p}=0.624$, which means there is no relationship between condom availability and HIV status.

\section{Relationship between reinforcing factors and HIV status}

Relationship between reinforcing factors in the form of family support and HIV/AIDS prevention 
behavior on HIV status and the number of respondents who stated HIV status as many as 36 respondents are shown in Table 7 and Table 8.

Table 7. Relationship between family support and HIV status

\begin{tabular}{lccc}
\hline & \multicolumn{2}{c}{ HIV Status } & \\
Reinforcement Factors & Positive & Negative & Total \\
\hline Poor family support & 12 & 22 & 34 \\
Good family support & 1 & 1 & 2 \\
\hline Total & 13 & 23 & 36 \\
\hline
\end{tabular}

Based on the Chi-square test result, the value of $p=0.598$ was obtained, which means that there was no difference between respondents with poor or good family support for HIV status. Based on the results of the calculation test contingency coefficient, the value of $p=0.674$ means that there is no relationship between family support and HIV status.

Table 8. Relationship between prevention behavior and HIV status

\begin{tabular}{|c|c|c|c|}
\hline \multirow{2}{*}{ Reinforcing Factors } & \multicolumn{2}{|c|}{ HIV Status } & \multirow[b]{2}{*}{ Total } \\
\hline & Positive & Negative & \\
\hline Bad preventive behavior & 12 & 2 & 4 \\
\hline Good preventive behavior & 11 & 21 & 32 \\
\hline Total & 13 & 23 & 36 \\
\hline
\end{tabular}

Based on the Chi-square test result, it was found that the value of $\mathrm{p}=0.459$, which means that there is no difference between respondents with bad or good prevention behavior towards HIV status. Based on the count test contingency coefficient results, the value of $\mathrm{p}=0.540$, which means there was no relationship between prevention behavior and HIV status.

\section{DISCUSSION}

\section{Distribution of respondents by age group}

Based on data from the Indonesian Ministry of Health in estimates and projections of HIV/AIDS in Indonesia for 2015-2020, the percentage of males aged 15-49 transgender is $0.06 \%$. According to the Indonesian Ministry of Health data, $85 \%$ of the respondents in this study were in the interval. In general, the respondent's age group is in the late adolescent phase to early elderly (Ministry of Health, Republic of Indonesia, 2009). Another result of a suitable study conducted by Awad et al. (2015) to 60 transgender respondents in Manado City stated that the dominant age group for shemale was 41-50 years (18.3\%), while the age group over 50 years was only one respondent (1.7\%) (Awad et al., 2015).

\section{Distribution of respondents based on last education}

Based on the results of the research conducted, it shows that the most recent respondent's education was senior high school, with 33 respondents $(41.3 \%)$ followed by junior high school with 21 respondents (26.3\%). A suitable study was conducted by Awad et al. (2015) to 60 transgender respondents in Manado City stated that most of the respondents' last education level was junior high school/equivalent with a percentage of $38.3 \%$ and followed by senior high school with a percentage of 25\% (Awad et al., 2015). Research by Rahmayani et al. (2014) on 40 transgender respondents in Padang City showed that the latest level of education of the respondents was Senior high school/Vocational high school (Rahmayani et al., 2014).

\section{Distribution of respondents based on type of work}

Based on the research results, it shows that the distribution of respondents based on the type of work is dominated by private employees with a total of 38 respondents (47.4\%) and followed by salon employees with the number of respondents $22(27.5 \%)$. Meanwhile, there were 8 respondents (10\%) who work as sex workers. Similar results were also found in the study of Awad et al. (2015) to 60 transgender respondents in Manado City, 25 respondents worked as salon workers (41.7\%), and 50\% worked as prostitutes (Awad et al., 2015). Another case with research conducted by Firmansyah et al. (2018) on 40 transgender respondents in Manado City showed that shemale had the most jobs as 
entrepreneurs, namely 42.5\%, and the least as students, namely 5\% (Firmansyah, et al. 2018). Based on several studies, in general, shemale have jobs to earn a regular income every month.

\section{Relationship between presdiposing factors and HIV status}

Based on the analysis results using the test, it was contingency coefficient found that there was no relationship between knowledge of HIV/AIDS and the HIV status of respondents $(p=0.729)$. A total of 6 respondents with poor knowledge stated positive HIV status, and 7 respondents who had good knowledge stated that they were HIV positive. Meanwhile, 12 respondents who had bad knowledge stated negative HIV status, and 1 respondent who had good knowledge stated negative HIV status. Based on the analysis results using the test Chi-square, there was no difference between the respondents with knowledge of HIV/AIDS, which was bad or good about their HIV status ( $\mathrm{p}=0.5$ ).

This discrepancy is explained by Everett Rogers about change by emphasizing the background of the individuals involved and the environment in which the change is implemented. Roger explains the 5 stages of change, namely: awareness, desire, evaluation, trying, and acceptance, also known as AIETA (Awareness, Interest, Evaluation, Trial, and Adoption). Respondents are at the stage awareness where respondents have an awareness of HIV/AIDS incidents but are not interested in making changes, so that good knowledge of HIV/AIDS is not related to the respondent's HIV status (Arku, 2012).

\section{Relationship between enabling factors and HIV status}

Based on the results of the analysis using the test, the contingency coefficient found no relationship between the availability of condoms and the HIV status of the respondents $(\mathrm{p}=0.624)$. A total of 5 respondents who had poor condoms' availability stated their HIV positive status, and 8 respondents who had good condom availability stated their HIV positive status. Meanwhile, as many as 7 respondents who had bad condom availability stated negative HIV status, and 16 respondents who had good condom availability stated negative HIV status. Therefore, based on the analysis results using the test Chisquare, there was no relationship between respondents and the availability of bad or good condoms on HIV status ( $\mathrm{p}=0.447$ ). This discrepancy may be caused by improper storage of the condom, causing the condom to break and not function optimally. In addition, improper and inconsistent use of condoms can also lead to incompatibility (Jatmiko, et al., 2010).

\section{Relationship between reinforcing factors and HIV status}

Based on the analysis results using the test, the contingency coefficient found that there was no relationship between family support and the HIV status of respondents $(p=0.674)$. A total of 12 respondents who had poor family support stated their HIV positive status, and 1 respondent who had good family support stated that they were HIV positive. Meanwhile, 22 respondents with poor family support stated negative HIV status, and 1 respondent who had good family support stated negative HIV status. Therefore, based on the analysis results using the analysis using the Chi-square test, there was no difference between respondents with poor or good family support for HIV status $(\mathrm{p}=0.598)$.

Discrimination from society in individual psychology can lead to increased feelings of inferiority in a person (Yustinus \& Semiun, 2013). These feelings then make them socialize more with each other or in the community. So that the opportunity for transgender people to change the stigma of society is getting smaller because most of them choose to limit themselves and be in the comfort zone (Saraswati et al., 2017). This is why there is no relationship between family support and the respondent's HIV status because respondents feel they do not need family.

Based on the analysis results using the test, it was contingency coefficient found that there was no relationship between prevention behavior and the respondent's HIV status $(\mathrm{p}=0.540)$. A total of 12 respondents who had bad preventive behavior stated that they were HIV positive, and 11 respondents who had good preventive behavior stated that they were HIV positive. Meanwhile, 2 respondents who had bad preventive behavior stated negative HIV status, and 21 respondents who had good preventive behavior stated negative HIV status. Therefore, based on the results with the Chi-Square test, there was no difference between respondents with bad and good prevention behavior towards HIV status $(\mathrm{p}=0.459)$. This mismatch is probably due to the fact that respondents are more indulgent in emotions, namely wanting to get partner satisfaction and more material without thinking about the risks that will occur, feeling ashamed to buy condoms, and having the perception that condoms can reduce pleasure during sexual intercourse (Eda et al., 2012). 


\section{CONCLUSION}

The characteristics of shemale in Surabaya based on sociodemography showed that the largest age group was $42-46$ years $(22.5 \%)$, the latest education level of shemale was dominated by senior high school (41.3\%), and the most types of work were private employees (47.4\%). The predisposing factors showed that there were 37 shemale $(46.3 \%)$ who had good knowledge of HIV, the enabling factors indicated that there were 56 shemale (70\%) stated that the availability of condoms in sexual intercourse, the reinforcing factor in the form of family support showed that as many as 5 shemale $(6,3 \%)$ received family support regarding information on HIV/AIDS and HIV/AIDS prevention behavior, indicating that as many as 60 shemale (75\%) used condoms and lubricants during sexual intercourse and other preventive measures. Out of a total of 80 respondents, only 36 respondents stated their HIV status, with 13 shemale having a positive HIV status and 23 shemale having a negative HIV status. There was no relationship between risk factors that influenced HIV/AIDS incidence among shemale and their HIV status.

\section{REFERENCES}

Arku, J., 2012. The "AIETA Model" of communication as propounded by Everett Rogers in his book "Diffusion of Innovation". Downloaded 18 August 2019 from http://jassyarku.blogspot.com/ 2012/09/the-aieta-model-of-communication-as.html

Awad, L., Elim, C., Anita, D., Ekawardani, N., 2015. Perbedaan tingkat pengetahuan dan sikap tentang HIV/AIDS pada waria pekerja seks komersial dan waria non-pekerja seks komersial di Kota Manado [Difference of knowledge and attitude on HIV/AIDS among female commercial sex workers and noncommercial sex workers in Manado]. Journal e-Clinic (eCl). 3(1): 463-9.

Eda, N., Widjanarko, B., Widagdo, L., 2012. Niat penggunaan kondom pada komunitas waria di Kota Ternate [Intention to use condom among shemale community in Ternate]. Jurnal Promosi Kesehatan Indonesia. 7(2): 174-10.

Firmansyah, F., Asrifuddin, A., Kalesaran, A., 2018. Gambaran epidemiologi dan pengetahuan HIV/AIDS pada waria di Kota Manado tahun 2018 [Profile of HIV/AIDS epidemiology and knowledge among shemale in Manado in 2018]. Jurnal KESMAS. 7(4).

Jatmiko, A., Martodihardjo, S., Dewi, D., 2010. Peranan kondom pada penderita HIV [Role of condom in HIV patients]. Berkala Ilmu Kesehatan Kulit dan Kelamin. 22(1): 45-4.

Marubenny, S., Aisah, S., Mifbakhuddin, 2013. Perbedaan respon sosial penderita HIV/AIDS yang mendapat dukungan keluarga dan tidak mendapat dukungan keluarga di Balai Kesehehatan Paru Masyarakat (BPKM) Semarang [Difference in social response among HIV/AIDS patients receiving and not-receiving family support at BPKM Semarang]. Jurnal Keperawatan Komunitas, vol 1, pp 4351 .

Ministry of Health, Republic of Indonesia, 2007. Laporan Survei Terpadu Biologi dan Perilaku, analisis kecenderungan perilaku berisiko terhadap HIV di Indonesia [Integrated Survey Report on Biology and Behavior, analysis of predisposing risky behavior to HIV in Indonesia]. Jakarta: Ministry of Health, Republic of Indonesia 2009.

Ministry of Health, Republic of Indonesia, 2007. Pedoman nasional terapi antiretroviral: Panduan tatalaksana klinis infeksi HIV pada orang dewasa dan remaja [National guidelines for antiretroviral therapy: Guidelines of clinical management for HIV infection in adults and young adults]. Jakarta.

Ministry of Health, Republic of Indonesia, 2009. Surveilans terpadu biologis perilaku pada kelompok beresiko tinggi di Indonesia, rangkuman surveilans waria [Integrated biological surveillance in high risk group in Indonesia, a summary of surveillance to shemale]. Kerjasama Depkes, BPS, KPA dan LSM Peduli AIDS. Jakarta.

Ministry of Health, Republic of Indonesia, 2015, Survei Terpadu Biologis dan Perilaku [Integrated Survey Report on Biology and Behavior]. Jakarta: Directorate General of Disease Control and Environmental Health. UNAIDS, 2016. Global AIDS Up Date 2016. [e-book]. Downloaded 31 May 2016 from http://www.unaids.org/sites/default/files/ media_asset/global-AIDS-update- 2016_en.pdf.

Ministry of Health, Republic of Indonesia, 2016. Profil kesehatan Indonesia tahun 2015 [Health profile of Indonesia in 2015]. Jakarta. 
Prabawanti, C., Bollen, L., Palupy, R., Morineau, G., et al., 2011. HIV, sexually transmitted infections, and sexual risk behavior among transgenders in Indonesia. AIDS Behav. 15(3): 663-73.,

Rahmayani, V., Hanif, A., Sastri, S., 2014. Hubungan pengetahuan dan sikap dengan tindakan pengetahuan penularan HIV- AIDS pada waria di Kota Padang Tahun 2013 [Correlation between knowledge and attitude with action on HIV/AIDS transmission among shemale in Padang, 2013]. Jurnal Kesehatan Andalan. 3(2).

Saraswati, L.D., 2017. Eksplorasi kepribadian waria dalam perspektif psikologi individual [Exploration of shemale personality in individual psychological perspective]. E-Journal Bimbingan dan Konseling Edisi 1 Tahun ke-6, 80-98.

Social Welfare Data and Information Center, 2010. Kementerian Sosial dalam angka pembangunan kesejahteraan sosial [Ministry of Social Affairs in developing social welfare. A profile]. Jakarta.

WHO, 2015. Global Summary of The AIDS Epidemic 2015.

Yustinus, Semiun, O.F.M., 2013. Teori-teori kepribadian psikoanalitik kontemporer-1 [Contemporary theories on psychoanalytic personality I]. Yogyakarta: Penerbit Kanisius. 